\title{
A Comparative Analysis and Enlightenment of Postgraduate Accounting Education between China and America
}

\author{
Zhengyong Zhang \\ Department of Accounting \\ Nanjing University of Finance \& Economics \\ Nanjing, China
}

\author{
Zhenkun Wang \\ Department of Accounting \\ Nanjing University of Finance \& Economics \\ Nanjing, China
}

\begin{abstract}
With the development of economic globalization, and the continuous upgrade and innovation of the development of modern enterprise. The training quality and training specifications of high level accounting personnel are confronting new and higher requirements. This paper studies the characteristics and development evolution of postgraduate accounting education in America, including the basic models, training objectives, training methods, curriculum and other aspects, and conducted a comparative analysis with China's accounting postgraduate education. Expecting to provide a reference for the cultivation of postgraduate accounting education in our country.
\end{abstract}

Keywords-Accounting postgraduate; Postgraduate education; Comparative analysis

I. A COMPARISON ON THE ENROLLMENT SYSTEM OF PostgRaduATE ACCOUNTING STUDENTS BETWEEN CHINA AND AMERICA

The American accounting postgraduate entrance examination is organized by the university autonomously, varying from universities in each state but having a lot of flexibility. The entrance examination results are not the only criteria for the admission of graduate students, focusing more on the comprehensive examination of students' abilities. And the guiding ideology is based on satisfying the requirements of national and economic development. Taking the market demand as the starting point, the professional and the number of students are mainly determined by it.

\section{A. The Enrollment System of American Accounting \\ Postgraduate}

The generally procedures are as follows: The generally procedures are as follows:

- submitting the proof of university academic performance;

- GRE results;

- two or three recommendation letters of professors;

- personal application.
Generally, there is a minimum admission criteria in each university. After reviewing the above materials, then interviewing, and the authority will ultimately determine the admission list, no longer taking the entrance examination. There are no age restrictions for admission. For the American graduate enrollment is not simply to take test scores as the only standard, they pay more attention to the comprehensive examination on a candidate, especially studying ability, the admission results are accurately and reliably. In addition, the admission of American accounting postgraduate is open to candidates from all countries.

ETS has set up more than 1,500 test centers in more than 150 countries and regions, providing GRE services for students who want to study for postgraduate degrees in America. It can be seen that the enrollment examination system for postgraduate education in the United States is open and universal.

\section{B. The Enrollment System of Chinese Accounting Postgraduate}

In China, the postgraduate entrance examination system is rigorous. The education authority sets the minimum standard for the total score and single subjects including foreign language, politics, professional courses, the admissions units must implement the principle of "guarantee quality, check strictly, fewer but better", determine the retest list in accordance with the planned enrollment figure from those who meet the minimum standards and hold the reexamination. However, due to the rigid rules of examination results and enrollment figure, re-examination is often a mere formality. In recent years, although the reexamination has been taken seriously, the weight is increasing, some schools even account for $40 \%$ in the total score, there is no doubt that the entrance examination results are decisive. 


\section{A COMPARISON ON THE CULTIVATING MODEL OF Postgraduate Accounting Students BetweEn ChinA AND AMERICA}

\section{A. The Cultivating Mode of American Accounting Postgraduate}

The training of accounting postgraduate students in America are distinctive, even from the world point of view. The graduate student system originated in Germany. The United States combined its early college system with the German research institute, and formed the postgraduate system on the basis of its college system - the American graduate education model. This model changed the personalized, nonformal characteristics of German postgraduate education model (master with apprentice), and formed a regular, professional graduate education model. This large-scale production model is an important institutional innovation, which is called "American model".

"American model" can be further divided into business academy model and economics academy model, that is, professional degree model and academic degree model. There is no doubt that education of business academy is created by the United States. The CEO of the Be Beyond website Xie Jinbo think that the United States is the first to create business academy education model. Due to its long history, this model today is combined case analysis with theoretical research, which is followed by global business academic. In the United States, business is highly respected, and the developed business economy atmosphere provides sufficient case support, economic assistance and teacher resources for business academic education. The business academy model is featured with short time, strong operation and practicality. The curriculum is very tight and students need to devote a lot of energy to learning. And the teaching method is mainly casebased teaching firstly set by Harvard University so that the pragmatism throughout. Business academy are usually two years to get a degree, belonging to the typical vocational education.

The economics academy model is similar to the business academy model in many aspects, but focusing more on the cultivation of student's research abilities, which is more likely to teach theories and is quite different from the pragmatic style of business academy. In the United States, the major curriculum of the economics department in research universities is divided into pre-courses and post courses. The first year are standardized courses, with macroeconomics, microeconomics, econometrics, etc. After the end of these courses, there is a comprehensive examination (also known as the qualification test), only those who get more than B can pass. And, this test using the elimination system, the elimination rate of some universities can reach up to one quarter.

The second year begins on the professional class, and also have a test at the end of year, only those who pass can start writing the paper. After the qualification examination, the number of people participating in the professional examination is relatively less, so the way is also flexible, students can choose closed-book or oral exam. Later, during the stage of academic research and thesis writing, there is no time limit, and the only standard to determine whether graduate or not is personal ability.

Whether business academy model or the economics academy model, they both implement the large-scale training mode, the first two years are concentrated, "fatigue bombing" compulsory course, so that all students can meet at least the same level and stand on the same starting line on the accumulation of basic knowledge and ability, using this way to ensure the average quality of graduates.

\section{B. The Cultivating Mode of Chinese Accounting Postgraduate}

In China, the education of postgraduate accounting students is usually based on the combination of the German tutor system and the American mass production system. That is, the students not only studying together but also have a fixed tutor to guide. However, because of the different understanding of postgraduate education in various universities, the curriculums are not the same. This approach ensures the differences in personnel training, but cannot guarantee the average level of postgraduates. Some universities may develop unsuitable courses due to the deviation of cognition. Some may lead to the difference in teaching content, due to the different understanding of courses from different teachers. Some have high requirements and may have introduced the elimination mechanism.

These differences lead to the level and ability of domestic accounting postgraduate students vary widely, some schools cultivate high-quality accounting personnel, while some of the postgraduates cannot find the work. Although there are differences in the training of students under the American model, the basic ability of all graduates can be guaranteed at least.

\section{A COMPARISON ON THE EDUCATION DEGREE MANAGEMENT OF PostgraduAte ACCOUnTING STUdents BETWEEN CHINA AND AMERICA}

\section{A. A Comparison on the Education Degree System of Postgraduate Accounting Students between China and America}

The degree system in the United States was established in nineteenth Century, which was based on the model of postgraduate education in Germany and the cultivation mode of the bachelor's degree in England. The educational system of a master's degree in American is generally within two years, of which learning courses is limited to one year.

The educational system of a master's degree in China is generally within three years, of which learning courses is limited to 1.5 to 2 years and leaving 1 to 1.5 years for the master's thesis writing. Of course, with the further strengthening of China's opening up to the outside world, many schools in China are also learning abroad, and gradually shortening the training period of master's degree, such as Peking University, Zhongshan University and others have implemented 2 years' system. For a long time, the main goal of Chinese postgraduate education is to cultivate the professionals of teaching and research. For the vast majority of students, the master's degree education is the end of their education life. 
Therefore, in the stage of postgraduate education, students are required to have the ability of teaching and scientific research.

\section{B. A Comparison on the Education Training Objectives of Postgraduate Accounting Students between China and America}

On personnel training, Graduate education in the United States always adhere to the main principles of innovation and scientific research. And the aim of the master's degree education is to cultivate the professionals who are eager to seek knowledge for the whole life and have the ability to engage in creative academic activities and scientific research. Based on this consideration, the school especially focus on the cultivation of students' research ability, from training programs to curriculum settings to teaching methods, everything serves for the target. The objectives of training program is clear and targeted. The goal of the postgraduate education of American Business Academy master's degree education is to meet the specific needs of the individual and the society, due to the professionalism of the Business Academy, schools are more likely to play the role of professional training. Therefore, the design of training programs fully take the actual needs of the society into account, highlighting the application of knowledge, and paying attention to effectiveness. The goal of the master's degree in China is:

- to have a solid foundation of theory and systematic expertise in this discipline;

- to have the ability to engage in scientific research or operate the specialized technical work independently.

It can be seen that, on the cultivation of postgraduate students in China and America, many foreign universities do not have a master's degree as an independent degree to grant, so there is little consistent and clear postgraduate training objectives, many universities regard the master degree as the process of a stage, which can be obtained through application. Of course, the business academy grants MBA an independent degree, and most of them are only awarded a master's degree, no bachelor's degree and doctor's degrees. However, in recent years, the employment status of accounting postgraduate shows that although the accounting graduate students are highly qualified personnel, they lack the practical ability generally. Due to the one-sided emphasis on the pure theory of teaching, paying less attention to linking theory with practice, students are busy learning and rarely have the opportunity to contact with society. Little known about the actual situation of the society, coupled with the lack of work experience, is one of the reasons causing the problem of college students' employment in recent years. The actual needs of the society, require a resolutely change on the cultivation of Chinese accounting postgraduate students. We must change the ultimate goal of teaching general theory, focus on linking theory with practice, pay more attention to the training of analyzing and solving problems of the students, and the ultimate goal of us is to cultivate the practical professionals who can apply knowledge into use.

\section{The Comparison of Accounting Graduate Curriculum Design in China and America}

The American research university curriculum design is also very characteristic. In order to improve the cultivation quality of graduate students, American universities generally attach importance to training courses and teaching theory, in the provision to participate in research work at the same time, according to different situations of various disciplines, the graduate program offers many courses in the basic theory, systematic and strict curriculum design and course teaching with the specific implementation measures. The setting of American accounting graduate courses keep up with the economic and social development, and make timely adjustments, which can be able to supplement talents of the U.S. economy and scientific research as soon as possible, is conducive to the graduates adapt well to the society and work. The Macroeconomics, microeconomics and Econometrics, always defined as the core curriculum, and strict examination to ensure the basic teaching effect, can rapidly form the students to learn to recognize the economic unification. After the end of the first year when the exam is passed, each student must determine their own research direction, and then, in the second years of study in the field of related courses, to deepen their understanding.

In China, single Chinese accounting graduate training target determines the courses of the single and rigid. Due to longterm China accounting postgraduate education goal is to train the scientific research personnel and training senior management for the enterprise, coupled with the China capital market started late, development is relatively backward, accounting graduate students in China curriculum is mainly focused on the basic theory of accounting, financial and other basic theory, long rigid curriculum design, can't keep up with the development needs of the accounting practice. However, this does not mean copying foreign textbooks and curriculum design. The national conditions are different, the requirements of the students are not the same. For example, now many domestic first-class universities generally adopt foreign books but, those cases are always from abroad, and Chinese practicality. So, for the preparation of teaching materials, Chinese scholars can borrow in Harvard's teaching system, add the domestic content, so that textbooks can be more representative, and improve learning effect. The formulation of curriculum standards should come from the needs of society, the knowledge structure and the ability of students to accept and some other aspects, which cannot completely copy the situation abroad. Some universities completely copy the Harvard teaching materials and courses, but the effect of teaching gap, this is the reason.

\section{Comparison of Chinese and American Accounting Graduate Education Methods}

American Universities pay great attention to training students' comprehensive ability, which is associated with the widely used participatory teaching way inseparable. Graduate students in the United States attaches great importance to classroom discussion, graduate students always consult reference books before class to preparing for class. In the class, teacher 's explanation focuses on the history of the subject development the process of discovery, background, thinking 
process of scientists, and then put forward the problem, let the students discuss and put forward their own views. American universities often carry out the Seminar, which is one of the important ways to cultivate the students' application ability. The United States attaches great importance to the independence of learning, so that graduate students have free more time. What's more, US also pay attention to case teaching and practice teaching, let the students join the practice and combine the knowledge and practice. American graduate students' education also pay attention to the interdisciplinary combination of college teaching, many of the school's accounting engineering by the business school, the school of management and the Department of mathematics jointly taught, co culture.

The courses of accounting graduate education in China, which always has a large amount, is mainly based on Classroom Teaching, dominated by teachers. This is helpful to the study of students systematically master the basic knowledge and new achievements in scientific research, but may become the obstacle of cultivating students' independent and innovation ability. If the teachers set up a large number of courses, with lack of interaction between teachers and students, then students will be passive in studying. What's worse, selfstudy and discussion time will not be enough at all, so that the limited study will be useless. In practical training, the lack of strict, standardized, regular training, graduate students participate in the teaching practice is not enough. We should learn from American case teaching and academic discussion to strengthen graduate students' participation ability and selflearning ability.

\section{E. A comparative Study on the Screening and Elimination System of Chinese and American Accounting Postgraduates}

American Graduate Education carry out strict elimination system, graduate enrollment rate is high, and the elimination rate is very high as well. There are always some students can't get a degree every year. The elimination rate of Graduate School of General Studies is $10 \%-15 \%$, and some famous universities can reach $30 \%-40 \%$.

However, Chinese graduate elimination rate is very low. The postgraduate education pay too much attention to the exam, but contempt the learning process. During the graduate school, there are no other forms of examination in addition to the course examination. As long as the students can finish the compulsory course, within the specified time to complete the exam, and complete the thesis and reply in the last year, then they can grant graduate degrees. In fact there are few students for thesis unqualified get a diploma. This formed research generally existed in the entrance before hard, bad phenomenon after school play energetically. What's more, this is not conducive to stimulate the graduate students desire to learn and improve the overall quality of graduate students.

\section{CONCLUSIONS AND IMPLICATIONS}

Through the comparison, we can see that the Sino-US graduate student education in accounting research are different in many aspects, from the accounting postgraduate enrollment, accounting graduate training mode, and then to graduate in accounting assessment methods, Sino-US postgraduate education are different more or less. The reason mainly lies in the following aspects:

\section{A. The Economic Development Level and Period Are Different}

The United States is the most developed country in the world economy, the economic development provides a better economic foundation and more investment for accounting graduate education; By comparison, China is still in developing ranks, there is great difference between China's economic development level and the United States, and it is not possible that this does not affect the China accounting graduate education.

\section{B. The Education Ideas Are Different}

The United States advocates a high degree of freedom, innovation and change. According to the ideas and thinking, cultivation of American accounting postgraduate education attaches great importance to innovation ability and practical ability; In contrast, affected by the long-term planned economy system, in China, all actions and the measures are strictly in accordance with the plan, which bring about the lack of innovation ability and the rigid education of higher education institutions and accounting graduate.

\section{The Way of Learning from Others Is Different}

The American educational system is formed by the extensive learning and innovation from the European countries. In terms of higher education, although the United States has been to learn from Europe, but building a system that the laymen includes government management departments involved the board of directors of the American higher education system. The circumstance that government involved in decision-making, but only through the local government investment and made part of the right to speak on the individual university decision-making, should be regarded as a situational factors of higher school faces, which belongs to a part of autonomous decision-making of colleges and universities, which is not the same meaning with government regulation. Higher education in China has been too much emphasis on the system learning, which often easily lead to government regulation, the government regulation is the inhibition of spontaneous order in Higher Education. The orientation of colleges is usually not innovating independently on the basis of independent decision-making, and higher education are often lack of innovative space and ability.

From the comparative study of Chinese and American Accounting Education and American accounting graduate education advanced training mode, we can get a lot of inspiration, American accounting graduate education has a lot to learn for us.

\section{Cultivating the Innovative Ability of Graduate Students Is Most Important}

Innovation is the soul of a nation, creative talents are the major carrier of national spirit. The accounting industry is always with high risk and fierce competition, to be in an invincible position in the enterprise financial competition, students must have a impressible sense of innovation and 
strong innovation ability; innovation is endless, so that without innovation they will be nobody. As a base for training the college should pay attention to the cultivation of students' innovative consciousness and innovative ability of students to training senior accounting talents with strategic vision and perspective of financial financing, investment, financing innovation.

\section{E. Improve the System of Postgraduate Enrollment and the Number of Years in China}

In the innovation of the graduate entrance examination system in China, Enrollment examination management system should be first adhered, enrollment unit autonomy should be expanded at the same time. New enrollment management system should reflect the "people-oriented", the power step by step down, the administration authority of postgraduate entrance examination should be controlled by enrollment unit eventually. To improve the quality of graduate students, the new pattern of graduate entrance examination should be based on the successful experience at home and abroad of entrance examination system, combined with the specific situation of China, a scientific system should be establish by the emphasis on the transformation from simplex knowledge to the comprehensive quality type with knowledge, ability (especially innovation ability), and gradually formed the system with Chinese characteristics and the world of postgraduate entrance examination system. According to the American graduate education experience, taking into account that the graduate students are mostly engaged in the practical work, so that the training period of graduate students can be shortened, and it is seemly better that the period is shortened to 1-1.5 years.

\section{F. Clear the Training Objectives And Difference Between Academic Degree and Professional Degree}

With the rapid expansion of Chinese postgraduate education scale, training objectives should have clear positioning suitable for China's national conditions, which is the historical development of the graduate education requirement at present. When it comes to setting the training goal, on the one hand, the needs of China's economic development should be considered. on the other hand, according to the different demand of the enterprise for talents, follow the principle of division of labor in the process of cultivation, respectively determine the training goal of personnel at all levels. Referring to the training of American accounting graduate, accounting graduate students should be divided into occupation and academic distinction. Vocational graduate students should be able to engaged In the field of accounting practice as soon as possible, the training should focus on the use of occupation ability and practice ability; whereas academic graduate student major in academic research and teaching work, so that it is necessary to strengthen the training of theoretical knowledge and the cultivation of scientific research ability.

\section{G. Optimize the Curriculum and Teaching Methods}

The course setting and change of accounting graduate should follow the development of social and economic, increase the number and rate of elective courses, it should be possible for the students to choose any courses by their own hobbies. What's more, the course selection of cross specialty or college should be allowed to expand students' knowledge. In the training methods, pay attention to the cultivation of interdisciplinary and the joint training of different colleges. In the teaching content, we must pay attention to the teaching of the theory of macro accounting, but also with the future development trend of accounting. In the teaching method, we should combine the classroom teaching with the discussion, focus on the cultivation of students' comprehensive ability, pay attention to the case teaching and practice teaching, to invite more famous people in practice to do lectures or teaching if possible.

\section{H. Import Elimination Mechanism to Improve the Quality of Graduate Students}

In recent years, the graduate education in China is mainly devoted to the expansion of scale, but some new problems in the aspects of content enrichment and quality management come out at the same time. Graduate system that "difficult admission with easy graduation" in China does harm to stimulate students' enthusiasm for learning and the spirit of climbing academic peak. Strengthening the quality management of accounting graduate students, and strengthen the strict examination of the quality of graduate research, improving the quality of graduate thesis, importing elimination mechanism is actually benefit to graduate develop the ability of adapting to the development of market economy actively, enhance the development ability and competitive ability.

\section{REFERENCES}

[1] X. Chen, W. Cui, "Research on the training mode of Chinese and foreign accounting Postgraduates". Finance and Accounting Monthly, pp. 64-66, June 2007.

[2] M. Li. "Thoughts on the cultivation of Postgraduates of accounting major under the new situation". Journal of Jiangxi University of Finance and Economics, pp. 101-106, April 2006.

[3] H. Wang, P. Zheng. "Reflections on the education of master degree in accounting major in China”. Accounting Study, pp. 69-72, July 2005.

[4] Y. Liu, G. Sun. "The present situation and countermeasures of accounting education and accounting education in China”. Accounting Study, pp. 75-79, February 2004.

[5] J. Zhu, C. Hu. "The present situation and innovation of accounting postgraduate education”. Financial Communications, pp. 123-125, May 2007.

[6] Sajjad ur Rehman, Bibi Alajmi, (2017) "Knowledge organization content in graduate coursework", Library Review, Vol. 66 Issue: 1/2, pp.90-106

[7] Taran Thune, Liv Anne Støren, (2015) "Study and labour market effects of graduate students' interaction with work organisations during education: A cohort study", Education + Training, Vol. 57 Issue: 7, pp.702-722

[8] X. Wan. On the reform and Countermeasures of postgraduate training mode of accounting major in China. New Accounting, pp. 15-17, August 2009 . 